J. Clin. Chem. Clin. Biochem.

Vol. 21, 1983, pp. 45-52

\title{
$\alpha$-Amylase Determination Using Maltopentaose as Substrate
}

\author{
By K. Larsen \\ Department of Clinical Chemistry Sønderborg Sygehus, Sønderborg, Denmark
}

(Received January 15/July 5, 1982)

Summary: The rationale of choosing a NADP-coupled continuous method, with the substrate maltopentaose, as a method for the determination of $\alpha$-amylase (EC 3.2.1.1) activity is investigated. The method presented is investigated with respect to all reaction parameters, including possible influence of protein, and shows zero order reaction kinetics after a 5-6 minute lag phase. The blank reaction from maltopentaose substrate is constant and is $13 \%$ of the upper limit of the reference interval for serum. The course of the blank reaction can be used to check that the maltopentaose is of adequate purity for use in the assay. $K_{\mathrm{m}}$ for maltopentaose is $0.48 \mathrm{mmol} / \mathrm{l}$. There is no interference from endogenous glucose when the total NADP turnover is less than $0.25 \mathrm{mmol} / \mathrm{l}$. Data for sensitivity, linearity and long term precision over an eighteen month period are given, together with reference intervals for serum and for urine. The method is recommended for consideration as a reference method.

\section{Bestimmung von $\alpha$-Amylase mit Maltopentaose als Substrat}

Zusammenfassung: Die rationelle Grundlage für die Wahl einer NADP-gekoppelten kontinuierlichen Methode mit dem Substrat Maltopentaose als Methode für die Bestimmung von $\alpha$-Amylase (EC 3.2.1.1) wurde untersucht.

Die beschriebene Methode wurde im Hinblick auf alle Reaktionsparameter, einschließlich eines möglichen Einflusses von Protein untersucht und zeigt nach einer 5 bis 6 minütigen lag-Phase eine Kinetik nullter Ordnung.

Die Blindreaktion des Maltopentaosesubstrats ist konstant und beträgt $13 \%$ der oberen Referenzwertgrenze für Serum. Der Verlauf der Blindreaktion kann als Grundlage für die geforderte Reinheit der angewandten Maltopentaose dienen.

$K_{\mathrm{m}}$ für Maltopentaose ist $0,48 \mathrm{mmol} / \mathrm{l}$. Es besteht keine Interferenz der endogenen Glucose bei einem totalen NADP-Umsatz von weniger als $0,25 \mathrm{mmol} / \mathrm{l}$.

Es liegen Daten vor über die Sensitivität, Linearität und Langzeitpräzision über eine 18 monatige Periode und Referenzwerte für Serum und Urin.

Die Methode wird für die Beưrteilung als Referenzmethode empfohlen.

\section{Introduction}

Methods for the determination of $\alpha$-amylase (1.4- $\alpha$ $D$-glucan glycanohydrolase) in biological fluids include starch-iodine (1), starch with measurement of reducing groups (2) and recently dye-labelled starch (3) methods. The newer NAD(P)H-coupled, continuous methods (4-8) have been developed for use in a variety of mechanized procedures.
No single method is generally accepted as a reference or recommended method. The evaluation of a method is therefore difficult, as correlation and regression studies are only of restricted value and in particular do not solve the main problem: The lack of standardization, when methods are used over longer periods, with different substrates and different substrate batches. 
The starch-reducing-group method (2) is generally used as a basis for nominal $\alpha$-amylase values in several commercial reference sera. However, calibration of other methods with such a reference serum is an arbitrary and unsatisfactory solution.

It is desirable to develop methods with well documented characteristics that fulfil the requirements for method standardization. The NADH methods reviewed by Lorenz (9) and Kaufman et al. (10) are potentially interesting in this connection. These methods measure glucose formed by coupled enzyme processes from the maltose formed by the hydrolytic action of $\alpha$-amylase on different oligo- or polyglucan substrates.

Substrates can be divided into polysaccharides, such as starch, that are chemically poorly defined, and well defined 1,4-oligosaccharides, such as maltotetraose and maltopentaose. On the basis of Robyt \& French's work (11), maltopentaose may be considered to be an ideal substrate, because active sites in porcine pancreatic amylase - which shows similarities to human pancreatic amylase - consist of 'five glucose' binding sites with the catalytic groups placed at the second binding site, so that hydrolysis of maltopentaose is dominated by the products maltose and maltotriose.

Maltopentaose is used - following preliminary removal of endogenous glucose - in the Du Pont method $(12,13)$, but basic and detailed method studies for this and other commercially developed NADH methods are lacking.

Therefore, the prerequisite for agreement on method standardization based on the molar absorbance of $\mathrm{NADH}$ is not fulfilled.

The present study concerns a maltopentaose method using NADP and without removal of endogenous glucose:

Maltopentaose

$\underset{\mathrm{EC} \text { 3.2.1.1 }}{\text { a-Amylase }} \longrightarrow \begin{aligned} & \text { Maltose }+ \\ & \text { Maltotriose }\end{aligned}$

Maltose+

Maltotriose

a-Glucosidase

EC 3.2.1.20

5 Glucose

5 Glucose +

5 ATP

Hexokinase

5 Glucose-6phosphate+ 5 ADP

5 Glucose-6phosphate+ $5 \mathrm{NADP}^{+}$
5 6-Phosphogluconate+ $5 \mathrm{NADPH}+5 \mathrm{H}^{+}$
Optimal reaction conditions, requirements for the purity of maltopentaose, and long-term reproducibility have been determined, in order to evaluate the overall potential of the method as a candidate reference method.

Preliminary to the study, maltopentabse (not commercially available - US patent 4039383) and other glucose homologues $\left(\mathrm{G}_{1}-\mathrm{G}_{13}\right)$ with 1.4 glucoside bonds were produced by partial acid hydrolysis of amylose and column chromatography of the hydrolysate using polyacrylamide gel (14), colümn eluates being identified with thin layer chromatography and quantified using a spectrophotometric phenol-sulphuric acid test.

\section{Materiạls and Methods}

Apparatus

LKB 8600 Reaction Rate Analyzer $37^{\circ} \mathrm{C}$ with plotter and $340 \mathrm{~nm}$ interference filter.

Reagents

Amylose, Merck 4561

Maltose, Mérck 5912

Maltotriose, Sigma grade II

HPTLC 'Fertigplatten', Kieselgel 60, Merçk

G-6-P-DH $(>75 \mathrm{kU} / \mathrm{l}) / \mathrm{HK}(>125 \mathrm{kU} / \mathrm{l})$, mixture in $50 \%$ glycerol, from Glucoquañ ${ }^{\circledR}$, Boehringer Mannheim Biochemicals. NADP-disodium salt $98 \%$ and ATP-disodium salt, Boehringer Mannheim Biochemicals.

Maltopentaose:

a) Donated by Lic. Techn. Bent Stig Ënevoldsen, Carlsberg Research Centre, Copenhagen, Denmark;

b) Donated by Noda Institute for Scientific Research, Japan;

c) Own production (14), together with maltohexaose and other maltosyl oligosaccharides.

The purity of different maltopentaoses is described in the section 'Experimental Results'.

Phosphate buffer reagent pH $6.8 \pm 0.05\left(20-25^{\circ} \mathrm{C}\right)$, containing the following ( $\mathrm{mmol} / \mathrm{i})$ :

Phosphate 70 , sodium chloride 51 , calcium chloride 0.6 , magnesium chloride 4, NADP 2.7 and ATP 1.5 (stäble for at least 5 months at $-20^{\circ} \mathrm{C}$ and at least 1 month at $+4^{\circ} \mathrm{C}$ ).

$\alpha$-Glucosidase solution (with ammonium sulphate $0.6 \mathrm{~mol} / \mathrm{l}$ ): $\alpha$ Glucosidase $250 \mathrm{kU} / 1$ (Boehringer Mannheim Biochemicals) is centrifuged and $4 / 5$ of the volume of supernatant containing ammonium sulphate $3.2 \mathrm{~mol} / 1$ is removed. The enzyme concentrate is diluted with $4 / 5$ volume of redistilled water (Stable at least 1 month at $4^{\circ} \mathrm{C}$ ).

Albumin dilution reagent, containing:

Human serum albumin, $\mathrm{Kabi}^{\circledR} 2 \mathrm{~g} / \mathrm{l}$ and sterile sodium chloride solution $9 \mathrm{~g} / \mathrm{l}$.

Other chemicals: all Merck analytical grade; 


\section{Specimens}

\section{Serum and urine}

Saliva, centrifuged, sterile filtered and diluted with sterile albumin dilution reagent.

Serum pools, enriched with $\alpha$-amylase from sterile filtered saliva, as well as serum pools with mainly pancreatic $\alpha$-amylase from patients with acute pancreatitis.

All serum and saliva samples were stored at $-20^{\circ} \mathrm{C}$ up to a maximum of 18 months, with no measurable change in $\alpha$-amylase activity. Urine samples were mixed, centrifuged and analysed on the day of sampling.

\section{Thin layer chromatography}

Glucose $\left(G_{1}\right)$ and other maltosyl oligosaccharides including maltopentaose $\left(G_{5}\right)$ and up to maltoundecaose $\left(G_{11}\right)$ can be identified by asccending thin layer chromatography on Merck HPTLC Kieselgel 60 using 2-propanol: acetone: lactic acid, $2+2+1$ (by vol.), and naphthoresorcin - sulphuric acid (Merck) as the location reagent.

Proposed $\alpha$-amylase assay procedure (see also tab. 1)

Phosphate buffer reagent

G-6-P-DH/HK mixture

$\alpha$-Glucosidase solution

Serum, urine or water (substrate blank)

Mix and incubate at $37^{\circ} \mathrm{C}(\min .5 \mathrm{~min}, \max .4$ hours $)$

Start reagent: Maltopentaose $24 \mathrm{mmol} / \mathrm{l}$

$1000 \mu \mathrm{l}$
$10 \mu \mathrm{l}$
$80 \mu \mathrm{l}$
$20 \mu \mathrm{l}$

$100 \mu \mathrm{l}$

Following a lag phase of $6 \mathrm{~min}, \Delta \mathrm{A}$ is measured at $37^{\circ} \mathrm{C}$ and $340 \mathrm{~nm}$ with one minute as assay interval.

The substrate blank $\Delta \mathrm{A}=0.007$ (constant) is deducted. Calculation of $\alpha$-amylase activity in the sample:

$$
\frac{\Delta A \min ^{-1}}{\varepsilon \times 5} \times \frac{1210}{20} \times 10^{5}=\left(\Delta A \min ^{-1}\right) \times 1945[\mathrm{U} / 1]
$$

Molar lineic absorbance of NADPH $(340 \mathrm{~nm})$ :

$$
\varepsilon=622 \mathrm{~m}^{2} / \mathrm{mol}
$$

The sample is diluted when the total absorbance at the end of the lag phase is higher than $A=1.6$.

\section{Experimental Resuilts}

The proposed assay procedure for determination of $\alpha$-amylase described above gives the reaction conditions described in table 1 . These conditions are based on a series of optimisation studies for the individual reaction parameters described below ( $\alpha$-amylase from a suitable dilution of saliva was used in these investigations, but all the results were also substantiated using human serum pools with mainly pancreatic $\alpha$-amylase). Reaction conditions in the figures shown and in the tables are, with the exception of the parameter under investigation, the same as those shown in table 1.
Tab. 1. Assay conditions in proposed $\alpha$-amylase assay.
Phosphate $(\mathrm{Na} / \mathrm{K})$

Sodium chloride

Calcium chloride

Magnesium chloride

Ammonium sulphate

ATP

NADP

Maltopentaose

$\alpha$-Glucosidase

Hexokinase

Glucose-6-phosphate dehydrogenase

Temperature

$\mathrm{pH}$

Serum volume fraction
$58 \mathrm{mmol} / \mathrm{l}$

$42 \mathrm{mmol} / \mathrm{l}$

$0.5 \mathrm{mmol} / \mathrm{l}$

$3 \mathrm{mmol} / \mathrm{l}$

$40 \mathrm{mmol} / \mathrm{l}$

$1.2 \mathrm{mmol} / \mathrm{l}$

$2.2 \mathrm{mmol} / \mathrm{l}$

$2.0 \mathrm{mmol} / \mathrm{l}$

$16 \mathrm{kU} / 1\left(25^{\circ} \mathrm{C}\right)$

$\geqslant 1.0 \mathrm{kU} / \mathrm{l}\left(25^{\circ} \mathrm{C}\right)$

$\geqslant 0.6 \mathrm{kU} / \mathrm{l}\left(25^{\circ} \mathrm{C}\right)$

$37{ }^{\circ} \mathrm{C}$

6.6

0.0165

\section{Buffer, $\mathrm{pH}$ and ion concentration}

Comparisons of acetate, tris and phosphate buffers show that phosphate is the most suitable, with an acceptable buffer capacity of $58 \mathrm{mmol} / \mathrm{l}$ at $\mathrm{pH} 6.6$ in the reaction mixture. Increasing the buffer concentration results in significant anion inhibition at concentrations above $100 \mathrm{mmol} / \mathrm{l}$. The optimal $\mathrm{pH}$ for the reaction mixture is $6.6 \pm 0.2$ (fig. 1 ).

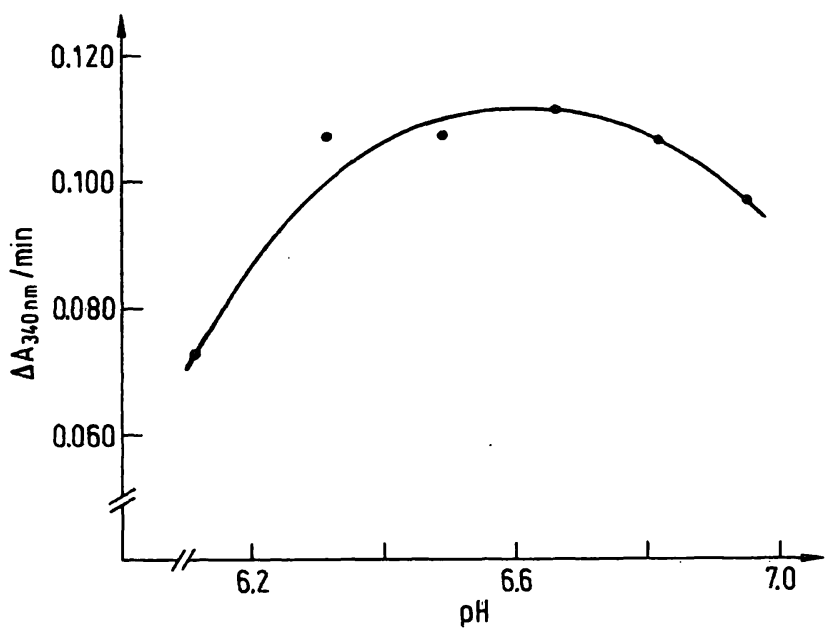

Fig. 1. Dependence of $\alpha$-amylase reaction rate on $\mathrm{pH}\left(37^{\circ} \mathrm{C}\right)$ in the reaction mixture. Assay conditions as given in tab. 1. Enzyme: Dilutions of saliva with albumin diluent.

\section{Chloride}

Increasing the concentration from 30 to $100 \mathrm{mmol} / \mathrm{l}$ increases the reaction rate to twice that of the rate without chloride. Higher concentrations of chloride cause inhibition.

\section{Calcium}

Calcium at $0.5 \mathrm{mmol} / \mathrm{l}$ activates slightly, and higher concentrations have a slight inhibitory effect on the reaction rate. 


\section{Magnesium}

Magnesium is known to be necessary for the glucose reaction system and was not investigated in the present study.

\section{Sulphate}

Sulphate ions from the $\alpha$-glucosidase preparation ${ }^{1}$ ) and added sodium sulphate inhibit the reaction as shown in figure 2 . Sulphate concentration in the proposed assay conditions is $40 \mathrm{mmol} / \mathrm{l}$ (tab. 1). Interpolation to zero sulphate concentration gives a maximal $4 \%$ greater reaction rate in the total reaction system. Inhibition is found to be about five times as great in the glucose indicator reaction, which is demonstrated by addition of glucose without $\alpha$-amylase. The lag phase for the two indicator reactions and for the total $\alpha$-amylase reaction system is increased at higher sulphate ion concentrations.

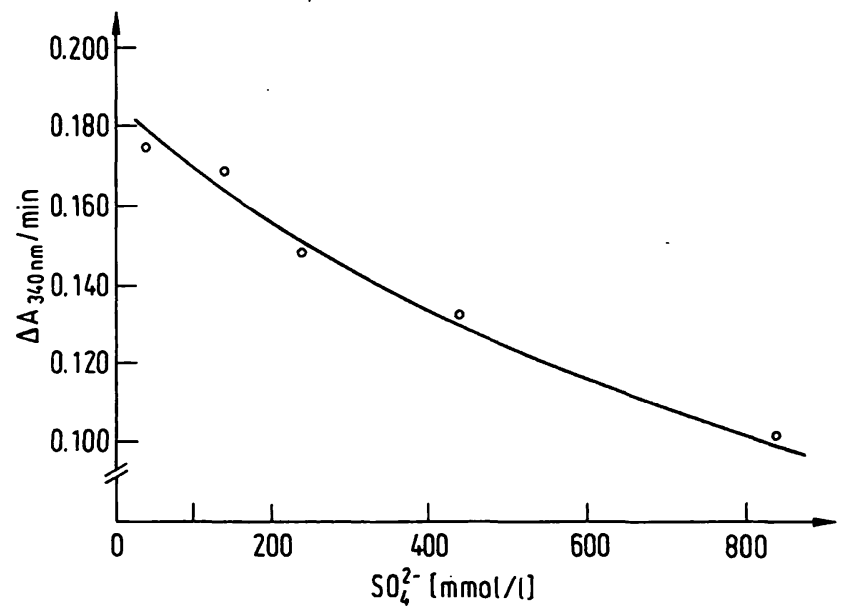

Fig. 2. Inhibition of $\alpha$-amylase reaction rate with sulphate ion, sulphate final concentrations originating from $\alpha$-glucosidase preparation (see tab. 1) and from added sodium sulphate. Assay conditions as given in tab. 1. Enzyme: Dilutions of saliva with albumin diluent.

\section{$\alpha$-Glucosidase}

$\alpha$-Amylase reaction rates were investigated at catalytic concentrations of $\alpha$-glucosidase between 2 and $32 \mathrm{kU} / \mathrm{l}$ at constant sulphate concentration and constant $\mathrm{pH}$. Between about 4 and $32 \mathrm{kU} / \mathrm{l}$, the maximum reaction rate is constant, but the lag phase varies between about $15 \mathrm{~min}$ at the lowest and 4-5 $\mathrm{min}$ at the highest concentration. A proportionally increasing maltopentaose blank reaction is also obtained with increasing catalytic concentration of $\alpha$-glucosidase', in as much as maltopentaose is also slowly hydrolysed by $\alpha$-glucosidase. The concentration of

1) Lyophilized $\alpha$-glucosidase became commercially available after the termination of this study. about $16 \mathrm{kU} / \mathrm{l}$ chosen in the proposed assay (tab. 1) gives a lag phase of 5-6 min, which is found to be constant and equal for different sources of $\alpha$-amylase (see 'specimens').

\section{Hexokinase and glucose-6-phosphate de- hydrogenase}

These auxiliary enzymes are present in the same concentrations as described for Glucoquant ${ }^{\circledR}$ for the determination of glucose. Halving or doubling the concentrations of both enzymes has no significant effect.

\section{ATP and NADP}

ATP $1.2 \mathrm{mmol} / \mathrm{l}$ and NADP $2.2 \mathrm{mmol} / \mathrm{l}$ were chosen after consideration of the results shown in figure 3. With a maximum turnoverer of ATP and NADP of $0.25 \mathrm{mmol} / 1$ in the reaction mixture, corresponding to a maximum absorption of $\mathrm{A}=1 . \overline{5}$, the $\mathrm{ATP}$ and NADP concentrations will still remain in the optimal ranges of concentration.

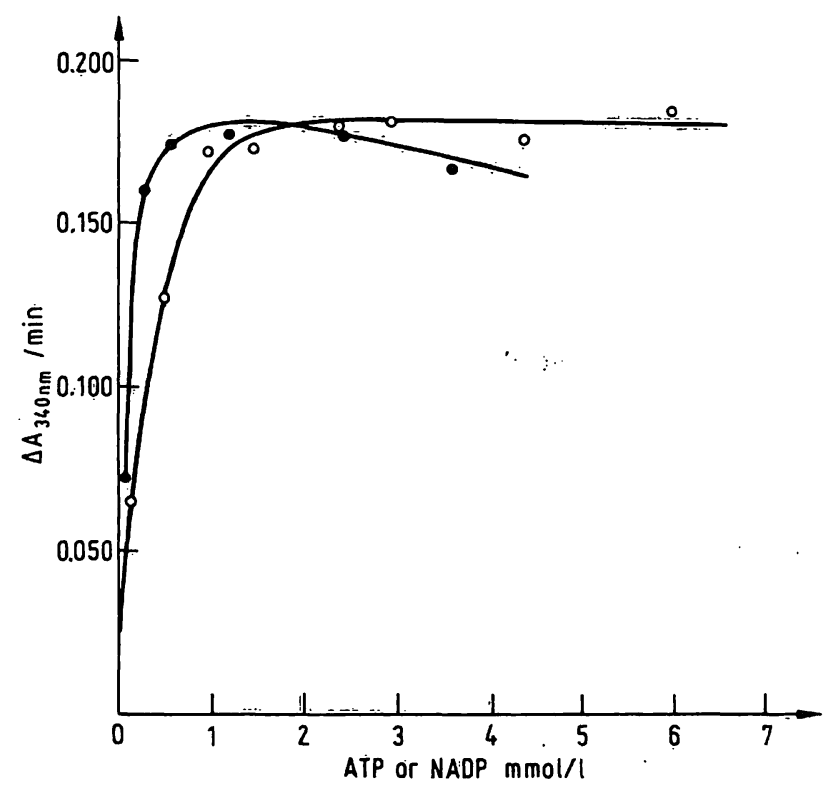

Fig. 3. Dependence of $\alpha$-amylase reaction rate on ATP ( -0$)$ and on NADP (O-O). Assay conditions as given in tab. 1. Enzyme: Dilutions of saliva with albumin diluent.

\section{Maltopentaose substrate}

Maltopentaose is used in the three grades $a, b$ and $c$.

a) is purified by paper chromatography;

b) has the following specifications: water 0:017, carbohydrate 0.983 , and an oligomer distribution côntaining maltopentaose 0.980 together with maltotetraose 0.002 and $\mathrm{G}_{6-8,0}$ ligomers 0.018 . 
c) has been compared with a) and b) using thin layer chromatography, which showed that all three grades were of the same purity.

$\alpha$-Amylase activities measured using the three grades of maltopentaose give similar results.

Following a suitable period of reaction at $37^{\circ} \mathrm{C}$, mixtures of $2 \mathrm{mmol} / 1$ maltopentaose in $\alpha$-amylase containing serum or in dilutions of serum with phosphate buffer $\mathrm{pH} 6.8$ were analysed by thin layer chromatography. In every case there were two reaction products, maltose and maltotriose, and less than 0.10 unhydrolysed maltopentaose.

Examination of the blank reaction of the total $\alpha$-amylase reaction system, in which the sample containing $\alpha$-amylase is replaced by distilled water (fig. 4), gives the best indication of the content of lower oligomers in the maltopentaose; the rate of reaction is greatest for glucose, and this reaction is seen in the first minute of the blank reaction; it is less for maltose and maltotriose, which react in the first 3-4 minutes, and least for maltotetraose, which gives the

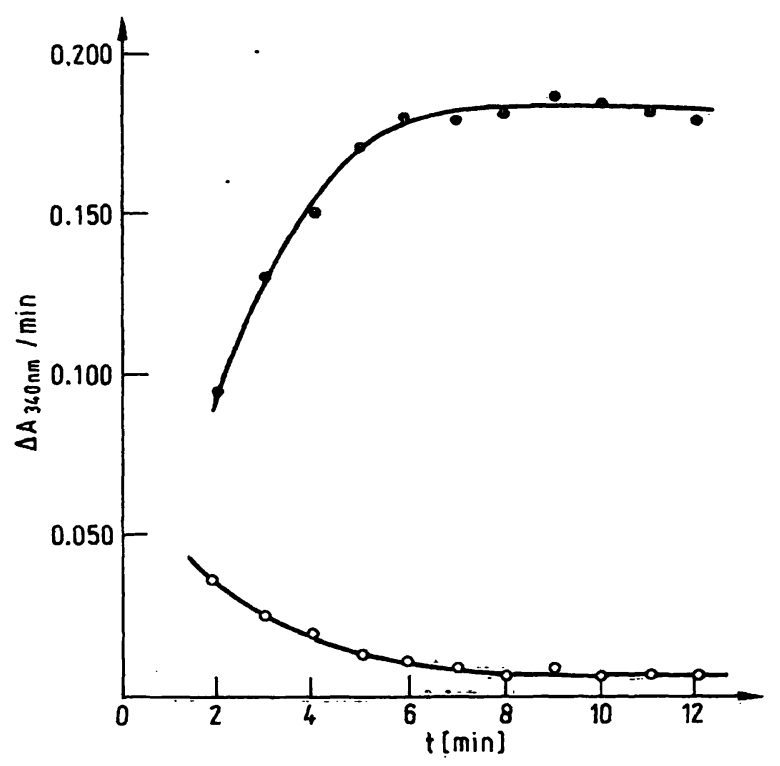

Fig. 4. Relationship between $\alpha$-amylase reaction rate on time of measurement for sample (-) and for reagent blank $(\mathrm{O}-\mathrm{O})$. Assay conditions as given in tab. 1. Enzyme: Dilutions of saliva with albumin diunent.

curved part of the reaction course in the last part of the lag phase. Finally, the blank reaction of maltopentaose is seen as a constant low reaction rate with $\Delta \mathrm{A} \min ^{-1}=0.007$. The results of experiments with low concentrations of glucose, maltose, maltotriose, maltotetraose and maltohexaose as substrates (for $\alpha$ glucosidase) in the $\alpha$-amylase reaction system, confirm the interpretation of the course of the blank reaction described above. Maltohexaose and higher glucose homologues (from our own preparation of maltopentaose) give no measurable blank reaction, and do not give a higher $\alpha$-amylase reaction rate.

\section{$K_{m}$ for maltopentaose}

The $K_{\mathrm{m}}$ for maltopentaose using a Lineweaver-Burk plot (fig. 5) is $0.48 \mathrm{mmol} / \mathrm{l}$. Two $\mathrm{mmol} / \mathrm{l}$ is chosen (tab. 1), because the greatest $\alpha$-amylase activity measurable with a linear response, $850 \mathrm{U} / 1$ in the sample, will convert about $0.05 \mathrm{mmol} / \mathrm{l}$ in the reaction lasting 7 minutes, i.e. a maximum of 0.02 of the substrate. Maltopentaose concentrations higher than $4 \mathrm{mmol} / \mathrm{l}$ give a maximum reaction rate (blank subtracted) about $17 \%$ higher, but the blank reaction due to maltopentaose is increased by a factor of 2 .

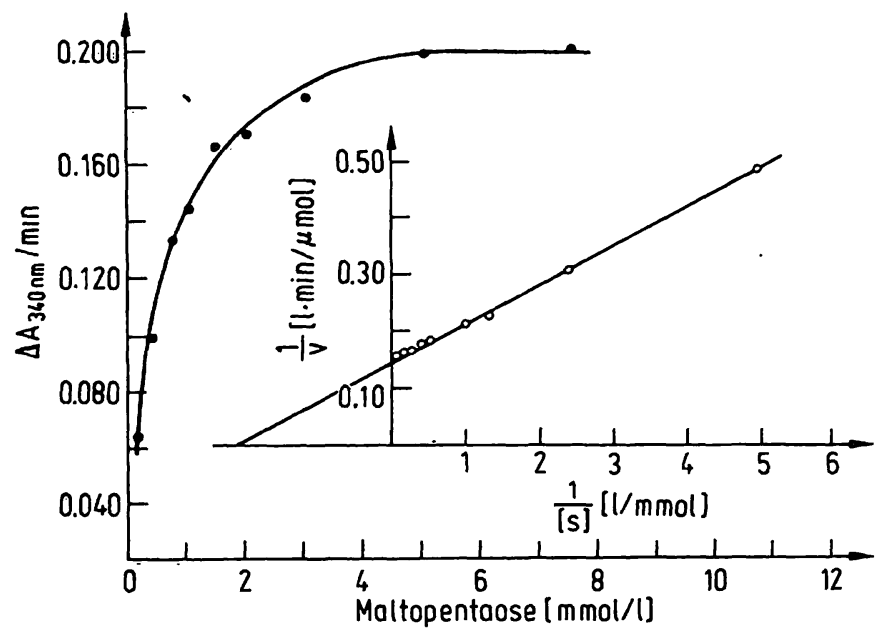

Fig. 5. Substrate curve and determination of $K_{\mathrm{m}}$ for $\alpha$-amylase with maltopentaose as a substrate by a Lineweaver-Burk plot. Assay conditions as given in tab. 1. Enzyme: Dilutions of saliva with albumin diluent.

Endogenous glucose and the serum blank reaction

Glucose from serum or urine will react completely in the $\alpha$-amylase reaction system during the lag phase; $\Delta \mathrm{A} \min ^{-1}$ after $5 \mathrm{~min}$ at $37^{\circ} \mathrm{C}$, and without maltopentaose in the reaction system is $0.000 \pm 0.002$. A variety of serum samples, including very icteric and lipaemic samples, also give serum blank values that are not significantly different from zero. Using the complete reaction system, $\alpha$-amylase activity is constant after addition of various glucose concentrations up to $12-14 \mathrm{mmol} / \mathrm{l}$ in the sample (tab. 2). Variations of glucose content in the samples and thus initial variations in NADP/NADPH ratios do not effect the $\alpha$-amylase activities measured for glucose 
concentrations up to twice the upper reference level for normal values. Higher glucose concentrations $(16-20 \mathrm{mmol} / \mathrm{l})$ give a slight negative interference.

Tab. 2. Effect of variable glucose concentration on measured $\alpha$ amylase activity.

\begin{tabular}{lrrrrrrrr}
\hline $\begin{array}{l}\text { Glucose } \\
\text { (mmol/l } \\
\text { in sample) }\end{array}$ & 0 & 2 & 4 & 6 & 8 & 12 & 16 & 20 \\
$\begin{array}{l}\alpha \text {-amylase } \\
(\mathrm{U} / \mathrm{l})\end{array}$ & 149 & 147 & 144 & 143 & 141 & 143 & 137 & 129 \\
$(\overline{\mathrm{x}}, \mathrm{n}=4)$ & & & & & & & & \\
\hline
\end{tabular}

Assay conditions as given in table 1. Enzyme: Constant concentration of saliva, diluted with albumin diluent.

\section{Linearity - the effect of protein}

Known dilutions of high catalytic activity serum with up to at least $850 \mathrm{U} / \mathrm{l} \alpha$-amylase activity (corresponding to the usable range of measurement with the apparatus concerned) give a linear response, i.e. zero order kinetic, and the activity-absorbance line goes through the origin. Variation of the protein content by diluting high $\alpha$-amylase serum with sodium chloride solution $9 \mathrm{~g} / \mathrm{l}$, or low $\alpha$-amylase serum has no influence either on the reaction rates measured per liter serum or on the range of linearity. Glucose concentrations in the sera used were about $4 \mathrm{mmol} / \mathrm{l}$.

Dilution 1:2 of 39 normal urines (see fig. 7), used to determine the reference range, gives corresponding results when the dilution is performed with sodium chloride $9 \mathrm{~g} / \mathrm{l}(\overline{\mathrm{x}}=288 \mathrm{U} / \mathrm{l})$, or with diluent containing albumin $4 \mathrm{~g} / 1$ and sodium chloride $9 \mathrm{~g} / \mathrm{l}$ ( $\bar{x}=291 \mathrm{U} / \mathrm{l})$; statistical comparison using Wilcoxon's matched-pairs test for the two sets of results gives $\mathrm{p}=0.10$. On the other hand, saliva only retains its $\alpha$-amylase activity when diluted with albumin diluent, and increasing dilution with sodium chloride $9 \mathrm{~g} / \mathrm{l}$ results in a total loss of activity in comparison with activities over $100 \mathrm{U} / \mathrm{l}$ in corresponding albumin-containing dilutions.

\section{Method data}

Data describing the method from the above studies and from precision and reference interval determination are collected in table 3 . The results for blank values are given as means and ranges for between- run determinations carried out over a period of 18 months. Between-run precision data are from a period of one year, including several changes of reagent batches. In addition, other precision data over a 18 months period using a variety of samples, as described in 'specimens', show coefficients of variation of $3-5 \%$ for $\alpha$-amylase activities $50-400 \mathrm{U} / \mathrm{l}$.

Tab. 3. Assay data for the proposed $\alpha$-amylase assay.

\begin{tabular}{|c|c|}
\hline $\begin{array}{l}\text { Lag phase } \\
\text { Measurement interval }\end{array}$ & $\begin{array}{r}5-\quad 6 \cdot \min \\
1 \mathrm{~min}\end{array}$ \\
\hline $\begin{array}{l}\text { Measurement interval } \\
\text { Serum blank }\end{array}$ & $0 \pm \quad 4 \mathrm{U} / 1$ \\
\hline Maltopentaose substrate blank & $14 \pm \quad 4 U / 1$ \\
\hline $\begin{array}{l}\text { Linearity } \\
\text { (with NADP tumover less than } 0.25 \mathrm{mmol} / \mathrm{l} \text { ) }\end{array}$ & $0 \div 850 \mathrm{U} / 1$ \\
\hline $\begin{array}{l}\text { Serum reference interval }(N=173) \\
\text { Urine reference interval }(N=39)\end{array}$ & $\begin{aligned} 30 & -112 \mathrm{U} / \mathrm{l} \\
& <600 \mathrm{U} / \mathrm{l}\end{aligned}$ \\
\hline \multicolumn{2}{|l|}{ Precision $^{a}$ ) } \\
\hline $\begin{array}{lll}\text { Within -run, mean } 174 \mathrm{U} / 1 & \mathrm{SD} \equiv 4.2 \mathrm{U} / 1 \\
\text { Between-run, mean } 179 \mathrm{U} / \mathrm{l} & \mathrm{SD} \equiv 7.9 \mathrm{U} / 1 \\
\text { Between-run, mean } 24 \mathrm{U} / 1 & \mathrm{SD}=2.3 \mathrm{U} / 1\end{array}$ & $\begin{array}{l}C V=2.4 \% \\
C V=4.4 \% \\
C V \equiv 9.5 \%\end{array}$ \\
\hline
\end{tabular}

a) Serum pool, $n=19$ for each determination.

Between-run values are calculated from meañs of triplicates assayed during a one-year period.

The reference interval for serum was determined ùsing a group of 173 outpatients over 18 years old, and with no known pancreatic or gạstro-intẹstinal diseases. The histogram in figure 6 shows a slightly right-skewed distribution. The $95 \%$ intervall calculated from log values is $30-112 \mathrm{U} / \mathrm{h}$.

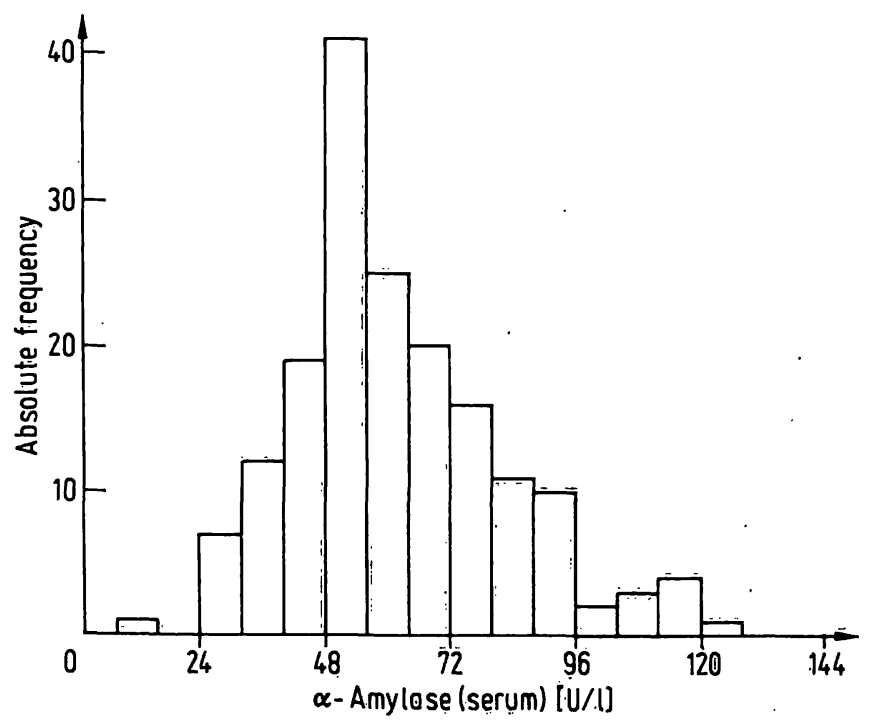

Fig. 6. Histogram of the serum $\alpha$ =amylase activity in 173 outpatients with no recognized disease of the pancreas - gastrointestinal systems. Assay conditions as given in tab. 1. 
For urine, the upper reference interval limit of $600 \mathrm{U} / \mathrm{l}$ is based on a group of 39 healthy hospital employees over 18 years old (fig. 7). The urine samples were taken at random and analysed on the same day as sampling.

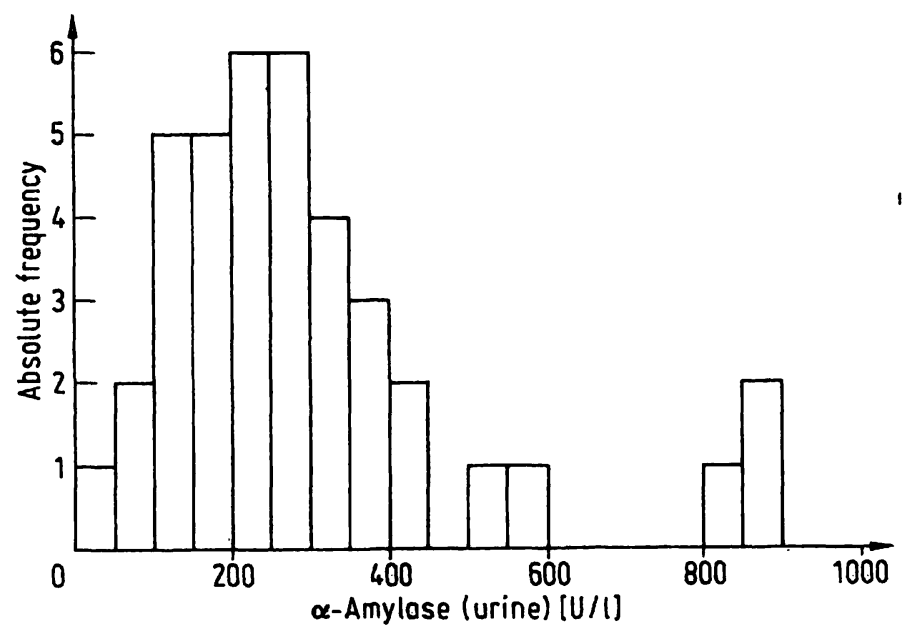

Fig. 7. Histogram of the urine $\alpha$-amylase activity in 39 healthy persons from the hospital staff. Assay conditions as given in tab. 1.

\section{Discussion}

A theoretical argument for chosing maltopentaose as a substrate is given in the study by Robyt \& French (6), mentioned above. The present study substantiates their findings that only maltose and maltotriose are formed by the action of human $\alpha$-amylase on maltopentaose.

The chosen reaction conditions give an apparently zero order reaction after a 5-6 minute lag phase. By setting a maximum limit of $A_{340}=1.6$ for the $a b-$ sorbance at the end of the lag phase, a linear response can be ensured for all samples, whatever their combined $\alpha$-amylase-glucose content and including the absorbance of the reagents and samples themselves.

The course of the substrate blank can be used as a basis of the requirements of purity for the maltopentaose used. Among the lower linear 1,4 glucose homologues $\left(G_{1}-G_{4}\right)$, maltotetraose could give a high and variable ('kinetic') blank value, depending on its concentration, the $\alpha$-glucosidase concentration and the chosen period of measurement.

In the study of linearity, the proteins of serum or urine samples did not influence the results for $\alpha$ amylase activity. Urine samples used to determine a reference interval show no significant differences with and without albumin addition, but experiments also show that saliva completely loses its activity when diluted with water or sodium chloride $(9 \mathrm{~g} / \mathrm{l})$, and retains it when there is protein in the diluent.

The method data in table 3 show that the present method has a high sensitivity and an excellent longterm reproducibility, even with several changes of reagent batch.

An overall comparison with the Du Pont aca $\alpha$-amylase procedure is made difficult by the lack of published information about reagent composition, especially buffer type, added activators and purity of maltopentaose. From the manufacturer's assay manual it can be seen that the chosen concentrations of the specified reactants do not differ essentially from the present method (tab. 1), differences being the preliminary removal of endogenous glucose, the use of NAD, and a total reaction time of $4.3 \mathrm{~min}$.

The main differences between the characteristics of the present method and the aca method are that the aca method is limited by measurement of a non-linear rate change in absorbance (13), and has a variable substrate blank of 100-120 U/1 (9); both features can be explained by contamination of maltopentaose with maltotetraose. Furthermore, albumin activation of urinary $\alpha$-amylase with the aca method $(13,15)$ contradicts the results of the present study, but the nature of possible protein interference is not clarified and needs further study. Finally, the originally reported aca reference interval shows an upper limit of $75 \mathrm{U} / 1$ (12) compared with $112 \mathrm{U} / 1$ in the present method, but it should be emphasized that the maximum obtainable activity using an assay system with a higher maltopentaose concentration of $4 \mathrm{mmol} / \mathrm{l}$ and with a sulphate-free $\alpha$-glucosidase preparation, is expected to give an upper limit of reference interval of about $140 \mathrm{U} / \mathrm{l}$.

\section{Conclusion}

In summary, it is concluded that maltopentaose, theoretically a well chosen and chemically well defined substrate for $\alpha$-amylase in the reagent system developed in the present study, is also suitable in practice, both for mechanized and for manual systems.

The method conforms to the majority of the requirements that can be made of a prospective reference method, especially concerning the important possibility of a reliable calibration based on the molar lineic absorbance of NADPH. 


\section{Acknowledgement}

This work was supported by the Medical Research Fund for the Hospitals in Ringkøbing, Ribe and South Jutland Counties. I thank Lic. Techn. Bent Stig Enevoldsen, Carlsberg Research Cen-

\section{References}

1. Street, H. V. \& Close, J. R. (1956) Clin. Chim. Acta I, 256-268.

2. Henry, R. J. \& Chiamori, N. (1960) Clin. Chem. 6, 434-452.

3. Ceska, M., Birath, K. \& Brown, B. (1969) Clin. Chim. Acta $26,437-444$.

4. Schiwara, H. W. (1972) J. Clin. Chem. Clin. Biochem. 10, 12-16.

5. Richter, R., Kemmler, A. \& O'Malley, J. A. (1973) Clin. Chem. 19, 644.

6. Wilson, C. S. \& Barret, M. J. (1975) Clin. Chem. 21, 947.

7. Pierre, K. J., Tung, K. K. \& Nadj, H. (1976) Clin. Chem. 22, 1219.

8. Hall, L. M. (1976) Clin. Chem. 22, 1219. tre, Copenhagen for supplying reference materials and for its valuable assistance in the preparation of maltopentaose, and the Noda Institute for Scientific Research, Japan, for making available maltopentaose. I am also very grateful for the interest and skilful work of the technical assistant Rita Bork.

9. Lorentz, K. (1979) J. Clin. Chem. Clin. Biochem. 17, 499-504.

10. Kaufman, R. A. \& Tietz, N. W. (1980) Clin. Chem. 26, 846-853.

11. Robyt, J. F. \& French, D. (1970) J. Biọl. Chem. 245, 3917-3927.

12. James, G. P., Passey, R. B., Fuller, J. B. \& Giles, M. L. (1977) Clin. Chem. 23, 546-550.

13. Balkcom, R. M., O'Donnel, C. M. \& Amano, E. (1979) Clin. Chem. 25, 1831-1835.

14. John, M. (1969) J. Chromatogr. 42, 476-484.

15. Garber, C. C. \& Carey, R. N. (1978) Clin. Chem. 24, 702-705.

Mr. K. Larsen, M. Pharm. Sc.

Dept. of Clinical Chemistry

Sønderborg Sygehus

P.O. Box 160

DK-6400 Sønderborg 